\title{
Follicle-stimulating hormone to substitute equine chorionic gonadotropin in the synchronization of ovulation in Santa Inês ewes
}

\author{
Bianor Matias Cardoso Neto ${ }^{1}$, Larissa Pires Barbosa ${ }^{1}$, Cristiane da Silva Aguiar ${ }^{1}$, Rosiléia \\ Silva Souza ${ }^{1}$, Ana Lúcia Almeida Santana ${ }^{1}$, Claudinéia Silva Mendes ${ }^{1}$, Patrícia Alves Dutra ${ }^{1}$, \\ Meiby Carneiro de Paula Leite ${ }^{1}$
}

1 Universidade Federal do Recôncavo da Bahia.

ABSTRACT - The substitution of equine chorionic gonadotropin (eCG) by follicle-stimulating hormone (FSH) in protocols for synchronization of ovulation in Santa Inês ewes was assessed. Ten females were submitted to the insertion of intravaginal sponges containing $60 \mathrm{mg}$ medroxyprogesterone acetate for 10 days; after this period sponges were withdrawn and the animals were randomly divided into two groups. Group $1(\mathrm{n}=5)$ : intramuscular injection of $0.5 \mathrm{~mL}$ d-cloprostenol and 300 UI eCG; Group $2(n=5)$ : intramuscular injection of $0.5 \mathrm{~mL}$ d-cloprostenol and $20 \mathrm{mg}$ FSH. Interval between sponge withdrawal and estrus beginning was $27.7 \mathrm{~h}$ and $35.9 \mathrm{~h}$ for eCG and FSH, respectively. Interval between sponge withdrawal and the end of estrus was $55.8 \mathrm{~h}$ for eCG treatment and $55.6 \mathrm{~h}$ for FSH treatment. Estrus length was $29.3 \mathrm{~h}$ and $19.6 \mathrm{~h}$, for eCG and FSH treatments, respectively. The biggest follicle and the second in size measured $0.74 \mathrm{~cm}$ and $0.54 \mathrm{~cm}$ for eCG treatment, whereas for the FSH treatment they measured 0.73 and $0.50 \mathrm{~cm}$. The interval between the beginning of estrus and ovulation was similar within all groups: $21.0 \mathrm{~h}$ for eCG treated ewes and $25.2 \mathrm{~h}$ for the ones treated with FSH. Ewes treated with eCG presented an interval of $47.5 \mathrm{~h}$ between sponge withdrawal and ovulation, while the ones treated with FSH presented a $61.1 \mathrm{~h}$ interval. Ovulation occurred $8.3 \mathrm{~h}$ before the end of estrus in the eCG group. On the other hand, ewes treated with FSH ovulated $5.5 \mathrm{~h}$ after the end of estrus. Estrus and ovulation were efficiently synchronized in Santa Inês ewes by using longterm progestogen protocol associated to the administration of $20 \mathrm{mg} \mathrm{FSH}$, along with Prostaglandin F2 $\alpha$ (PGF2 $\alpha$ ) at the moment of sponge withdrawal, thus substituting the use of eCG.

Key Words: estrus, follicular dynamics, real-time ultrasound

\section{Introduction}

The use of hormone treatments for estrus synchronization and ovulation leads to not only maximization in the use of males in reproduction programs, but also the concentration of births to a certain period of the year. This improves the nutritional management and female sanitation, favoring the obtainment of homogeneous offspring lots (Simplício et al., 2007).

The most frequently used methods for the synchronization of estrus and follicular growth stimulation in ewes use progesterone and/or progestogens in intravaginal sponges. They slowly release the hormone (Moraes et al., 2002; Dixon et al., 2006) and are frequently associated with the intramuscular administration of eCG to stimulate the follicle growth and the synchronization of ovulation (Ali, 2007). Prostaglandin F2 $\alpha$ (PGF2 $\alpha$ ) and its analogous can also be used due to their luteolytic effects (Dixon et al., 2006).

However, when repeated eCG injections are used, there is the production of anti-eCG antibodies. Hence, it interferes in the synchronization of estrus and ovulation with a decrease in the fertility rate due to the great variability in the number of ovulations and their timing (Noel et al., 1994). An alternative to the eCG treatment is the use of FSH, which presents a lower immune reaction (Nascimento et al., 2007).

That having said, the objective was to assess the use of FSH to substitute the eCG in protocols for the synchronization of ovulation in Santa Inês ewes. Assessment was done studying the estrus behavior and follicular dynamics.

\section{Material and Methods}

This experiment was performed in the Ovine Section of Universidade Federal do Recôncavo da Bahia (UFRB), in Cruz das Almas, Bahia, $12^{\circ} 40^{\prime} 0$ " South and 3906' 0 " West. The university is situated $200 \mathrm{~m}$ above the sea level, in a region of hot and wet tropical climate according to the Köppen classification. The annual rainfall average of the region is $1,224 \mathrm{~mm}$, with greater rain incidence between March and June. Relative humidity is approximately $80 \%$ and the annual temperature average is $24.5^{\circ} \mathrm{C}$. 
Ten Santa Inês ewes were selected, having an average weight of $44.3 \pm 2.7 \mathrm{~kg}$. They were non-lactating and their body condition score was between 2 and 3, in accordance with Morand-Fehr and Hervieu (1999). Ewes were in perfect health condition and were checked for the presence of follicles and/or corpus luteum in the ovary with the aid of ultrasound assessment.

Animals were submitted to intensive farming. During the day, the animals had free access to Pennisetum purpureum, and ground Cameron. They also received 300 g/day feed supplementation based on maize, wheat, soybean, and ovine mineral. Water and mineral were provided ad libitum.

All ewes received an intravaginal sponge containing 60 mg medroxyprogesterone acetate (MAP; Progespon ${ }^{\circledR}$, Syntex, Argentina) to be used for 10 consecutive days. At the moment of sponge withdrawal, ewes were randomly divided into two groups: Group $1(\mathrm{n}=5)$ : intramuscular application of $0.5 \mathrm{~mL}$ d-cloprostenol (Prolise ${ }^{\circledR}$, Arsa S.R.L., Argentina) and 300 UI eCG (Novormon ${ }^{\circledR}$, Syntex, Argentina) amd Group $2(\mathrm{n}=5)$ : intramuscular application of $0.5 \mathrm{~mL}$ d-cloprostenol and $20 \mathrm{mg}$ FSH (Folltropin ${ }^{\circledR}$, Bioniche, Canada).

Six hours after sponge withdrawal, all animals were monitored with a teaser ram at every two hours, in order to detect estrus. The moment in which the teaser started to demonstrate some interest upon the female was assumed as the beginning of estrus, and its end was determined by the end of receptivity and the diminishing of vulva edema.

The following reproductive behavior parameters were assessed: animals in heat due to treatment, interval between sponge withdrawal and beginning of estrus, interval between sponge withdrawal and the end of estrus, estrus length.

Ultrasound follicular dynamics assessments started 12 hours after sponge withdrawal, having an interval of 6 hours, finishing 6 hours after ovulation. Transrectal images were obtained using a $6.0 \mathrm{MHz}$ linear transducer (Pie Medical - Àquila Vet model). To find the ovary sites we followed the Ginther \& Kot protocol (1994). Only one technician performed the assessment; he jotted down and drew ovary diameters, position, and characteristics of ovary structures in every individual file.

The following follicular dynamics parameters were assessed: interval between the sponge withdrawal and ovulation, number of ovulations, follicle growth rate, ovary diameter and diameter of the biggest follicle and of the second follicle in size. Ovulation time was calculated using the average between the time that the biggest follicle was last seen and the time that ovulation was detected. The follicle growth rate (FGR) (mm/day) was obtained by the difference between the final diameter (fD) and the initial diameter (iD), divided by the number of hours (h) and multiplied by $24,(F G R=i D-f D / h \times 24)$ in order to obtain the daily follicle growth in accordance with Maffili et al. (2005).

The biggest ovary diameter was used to measure the ovaries in the position that they presented by the time of each evaluation. The follicular diameter was obtained by measuring the widest side of the antral cavity that measured $3 \mathrm{~mm}$ and onwards. The dominant follicle was assumed to be the one that presented the largest diameter of all follicles. Only one subordinate was considered, and it had to be one that had appeared at the same time as the dominant follicle, but with smaller diameter and smaller persistence.

The normality of the variables was assessed to analyze data. Variables without a normal distribution were assessed using the Wilcoxon non-parametric test, and variables with normal distribution were assessed using the Variance Analysis, with 5\% significance level.

\section{Results and Discussion}

All treated ewes (100\%) displayed estrus behavior after intravaginal sponge withdrawal. The interval between the sponge withdrawal and the beginning of estrus was $27.7 \mathrm{~h}$ and $35.9 \mathrm{~h}$ for animals of eCG and FSH treatments, respectively. There was no significant difference between them $(\mathrm{P}>0.05)$ (Table 1$)$

All animals that were in estrus proved the efficiency of both estrus synchronization treatment, which was in accordance with the results displayed by Almeida et al. (2007). They used short-term protocols with the application of $300 \mathrm{UI}$ eCG and $30 \mu \mathrm{g}$ d-cloprostenol or $50 \mu \mathrm{g} \mathrm{GnRH}$. The results from this research also go along with the ones found by Rodrigues et al. (2004), with the application of different eCG doses after the withdrawal of intravaginal sponge in cleanskin ewes.

Table 1 - Estrus behavior of Santa Inês ewes submitted to short term synchronization protocol substituting equine chorionic gonadotropin (eCG) by follicle-stimulating hormone (FSH)

\begin{tabular}{lcc}
\hline Parameters & eCG $(\mathrm{n}=5)$ & FSH $(\mathrm{n}=5)$ \\
\hline AE (\%) & 100 & 100 \\
ED (h) & $29.3 \pm 6.8 \mathrm{a}$ & $19.6 \pm 3.5 \mathrm{~b}$ \\
ISWBE (h) & $27.7 \pm 10.7$ & $35.9 \pm 6.4$ \\
ISWEE (h) & $55.8 \pm 7.5$ & $55.6 \pm 9.4$ \\
\hline
\end{tabular}

AE - animal in estrus; ED - estrus duration; ISWBE - interval between sponge withdrawal and the beginning of estrus; ISWEE - interval between sponge withdrawal and the end of estrus.

Means followed by different letters on the same row differ from one anothe through the variance analysis $(\mathrm{P}<0.05)$. 
The interval between the sponge withdrawal and the beginning of estrus was $27.7 \mathrm{~h}$ and $35.9 \mathrm{~h}$ for eCG and FSH- treated animals, respectively. This result was inferior to the $41.6 \mathrm{~h}$ found by Monte et al. (2007), who used 400 UI and $200 \mathrm{UI}$ eCG at the moment in which they had the sponge withdrawal of 30 Santa Inês cyclic ewes. On the other hand, Ali (2007) found an interval of $32 \mathrm{~h}$, studying cyclic Ossimi ewes using 350 UI eCG two days before the withdrawal of intravaginal sponge containing $40 \mathrm{mg}$ flurogestone acetate.

There was no significant difference $(\mathrm{P}>0.05)$ between groups for the interval between the sponge withdrawal and the end of estrus (ISWEE) (Table 1). Our results (eCG = 55.8 h; $\mathrm{FSH}=55.6 \mathrm{~h}$ ) were inferior to the $72.8 \mathrm{~h}$ found by Monte et al. (2007) in Santa Inês ewes.

Estrus duration differed between groups $(\mathrm{P}<0.05)$ (Table 1) $(\mathrm{eCG}=29.3 \mathrm{~h} ; \mathrm{FSH}=19.6 \mathrm{~h})$. The interval using eCG was similar to the $31.2 \mathrm{~h}$ interval found by Monte et al. (2007) using different dosages of eCG at the moment of sponge withdrawal.

The percentage of ovaries that were visualized during the follicular dynamics observation was $85.92 \%$, and there was no difference between the observations of the left and the right ovaries.

The ovary diameters of the left and right ovaries in the eCG group were 1.25 and $1.28 \mathrm{~cm}$, whereas the ones in the FSH group were 1.30 and $1.31 \mathrm{~cm}$ (Table 2). There was no significant difference between groups $(\mathrm{P}>0.05)$.

The biggest follicle measured $0.74 \mathrm{~cm}$ and $0.73 \mathrm{~cm}$, for eCG and FSH treatments, respectively (Tabela 2). There was no difference between groups $(\mathrm{P}>0.05)$. These numbers

Table 2 - Follicular dynamics in Santa Inês ewes submitted to protocols for the synchronization of ovulation using follicle-stimulating hormone (FSH) to substitute the equine chorionic gonadotropin (eCG)

\begin{tabular}{lcc}
\hline Parameters & eCG $(\mathrm{n}=5)$ & FSH $(\mathrm{n}=5)$ \\
\hline LOS $(\mathrm{cm})$ & $1.25 \pm 0.7$ & $1.30 \pm 0.1$ \\
ROS $(\mathrm{cm})$ & $1.28 \pm 0.1$ & $1.31 \pm 0.1$ \\
SBF $(\mathrm{cm})$ & $0.74 \pm 0.1$ & $0.73 \pm 0.1$ \\
SFS (cm) & $0.54 \pm 0.1$ & $0.50 \pm 0.1$ \\
ISWO (h) & $47.50 \pm 7.9 \mathrm{a}$ & $61.17 \pm 8.0 \mathrm{~b}$ \\
IBEO (h) & $21.07 \pm 7.7$ & $25.23 \pm 5.1$ \\
IEEO (h) & $-8.31 \pm 3.7 \mathrm{a}$ & $5.56 \pm 6.6 \mathrm{~b}$ \\
NO & $2.20 \pm 0.4$ & $1.80 \pm 0.4$ \\
FGR (mm/d) & $1.19 \pm 0.5$ & $1.27 \pm 0.5$
\end{tabular}

LOS - left ovary size; ROS - right ovary size; SBF - size of the biggest follicle; SFS - second follicle in size measurement; ISWO - interval between sponge withdrawal and ovulation; IBEO - interval between the beginning of estrus and ovulation; IEEO - interval between the end of estrus and ovulation; NO - number of ovulations; and FGR - follicle growth rate.

Means followed by different letters in the same row differ from one another through the variance analysis $(\mathrm{P}<0.05)$. were bigger than the $0.53 \mathrm{~cm}$ found by Uribe-Velásquez et al. (2002) for $500 \mathrm{UI}$ eCG and the $0.55 \mathrm{~cm}$ found by Tossi et al. (2009). Viñoles et al. (2001) discovered that the use of long-term protocols might lead to subluteal progesterone concentrations, and this would trigger an excessive follicle growth and the persistence of large follicles.

Measurements of the second-in-size follicle showed that they did not differ between treatments $(\mathrm{P}>0.05)(0.54 \mathrm{~cm}$ and $0.50 \mathrm{~cm}$ for eCG and FSH, respectively) (Table 2). The size of the dominant follicle observed by Uribe-Velásquez et al. (2002) (in Bergamácia ewes that used 0.3 g progesterone intravaginal sponge for 14 days along with the application of $500 \mathrm{UI}$ eCG at the moment of sponge withdrawal) was close in size to our second-in-size follicle. This puts some evidence on the existence of a co-dominance factor. According to Ginther (1993), this is a common characteristic, especially on the first and fourth follicle growth waves.

There were 2.2 ovulations on the eCG protocol, and 1.8 ovulations on the FSH protocol. Hence, there was no significant difference between them $(\mathrm{P}>0.05)$ (Table 2$)$. Vilariño et al. (2008) used 300UI eCG at the moment of the progesterone sponge withdrawal and obtained 1.5 ovulations. Ali (2007), working with two different eCG protocols (that had different moments for the eCG application) and one protocol without eCG, obtained the following results: eCG treatment $=2.33$ ovulation average; treatment without $\mathrm{eCG}=1.0$. This highlights the capability of eCG in triggering multiple ovulations.

The interval between the beginning of estrus and ovulation was similar between groups ( $\mathrm{P}>0.05)$. For the eCG group it was $21.07 \mathrm{~h}$ and for the FSH, it was $25.23 \mathrm{~h}$ (Table 2). As for follicle growth rate, the eCG group displayed $1.19 \mathrm{~mm}$ daily growth, whereas the FSH showed $1.27 \mathrm{~mm}$ daily growth $(\mathrm{P}>0.05)$ (Table 2$)$. This rate was bigger than the ones found by Tossi et al. (2009) and Ali (2007), which were $1.00 \mathrm{~mm} /$ day and $1.04 \mathrm{~mm}$ /day, respectively.

Ewes treated with eCG presented an interval of $47.50 \mathrm{~h}$ between the sponge withdrawal and ovulation. As for the FSH ewes, they presented a $61.17 \mathrm{~h}$ interval. Thus, there was significant difference between groups $(\mathrm{P}<0.05)$ (Table 2 ). Results for eCG treated ewes showed intervals similar to the ones found by Cavalcanti et al. (2007), who found $46.54 \mathrm{~h}$ when using 300 UI eCG and PGF2 $\alpha$ in Santa Inês ewes.

Interval between the end of estrus and ovulation was significantly different between groups $(\mathrm{P}<0.05)$. Ovulation occurred 8.31 hours before the end of estrus in the eCG group, and 5.56 hours after the end of estrus in the FSH group (Table 2). So it can be said that ovulation in the eCG group occurred 13 hours later than the ones in the FSH group. 


\section{Conclusions}

Estrus and ovulation were efficiently synchronized in Santa Inês ewes, by the use of long-term progestogen protocol associated with the administration of $20 \mathrm{mg}$ follicle-stimulating hormone along with Prostaglandin F2 $\alpha$, at the moment of sponge withdrawal. This is a possibility to substitute the equine chorionic gonadotropin protocol.

\section{References}

ALI, A. Effect of time of eCG administration on follicular response and reproductive performance of FGA-treated Ossimi ewes. Small Ruminant Research, v.72, p.33-37, 2007.

ALMEIDA, A.K.; CHALHOUB, M.; RIBEIRO FILHO, A.L. et al. Sincronização do estro e da ovulação com protocolos de curta e longa duração em ovelhas inseminadas por laparoscopia em tempo fixo. Acta Scientiae Veterinarae, v.35, Supl. 3, p.1039, 2007.

CAVALCANTI, A.S.; BRANDÃO, F.Z.; SILVA, A.L.S. et al. Uso do GnRH associado a protocolos de curta duração com esponjas de progestágenos para sincronização do estro em ovelhas. Acta Scientiae Veterinariae, v.35, Supl.3, p.1285, 2007.

DIXON, A.B.; KNIGHTS, M.; PATE, J.L. et al. Reproductive performance of ewes after 5-days treatment with intravaginal inserts containing progesterone in combination with injection of Prostaglandin F2 $\alpha$. Reproduction in Domestic Animals, v.41, p.142-148, 2006.

GINTHER, O.J.; KOT, K. Folicular dynamics during the ovulatory season in goats. Theriogenology, v.42, p.987-1001, 1994.

GINTHER, O.J. Major ad minor follicular waves during the equine estrous cycle. Journal of Equine Veterinary Science, v.13, p.18-20, 1993.

MAFFILI, V.V.; TORRES, C.A.A; FONSECA, J.F. et al. Sincronização de estro em cabras da raça Saanen com esponjas intravaginais e CIDR-G. Arquivo Brasileiro de Medicina Veterinária e Zootecnia, v.57, n.5, p.591-598, 2005.
MONTE, A.P.O.; NOGUEIRA, D.M.; SOUZA, P.H.F. et al. Efeito da dose de eCG na atividade estral e taxa de ovulação de receptoras de embrões ovinos. Acta Scientiae Veterinarae, v.35, Supl.3, p.1227, 2007.

MORAES, J.C.F.; SOUZA, C.J.H.; GONÇALVES, P.B.D. Controle do estro e da ovulação em bovinos e ovinos. In: GONÇALVES, P.B.D.; FIGUEIREDO, J.R.; FREITAS, V.J.F. (Eds.) Biotécnicas aplicadas à reprodução animal. São Paulo: Varela, 2002. p.25-55.

MORAND-FEHR, P.; HERVIEU, J. Apprécier l'éat corporel des chèvres: Intérêt et méthod. Reussir La Chevre, n.231, p.22-34, 1999.

NASCIMENTO, A.A.C.; TORRES, C.A.A.; DIAS, M. et al. Dinâmica folicular na sincronizacão de ovulação associado à administração de FSH-p em vacas da raça Nelore. Acta Scientiae Veterinarae, v.35, Supl.3, p.1320, 2007.

NOEL, B.; BISTER, J.L.; PIERQUIN, B. Effects of FGA and PMSG on follicular growth and LH secretion in Suffolk ewes. Theriogenology, v.41, p.719-727, 1994.

RODRIGUES, L.F.S.; ARAUJO, A.A.; NUNES, J.F. et al. Sincronização do estro em ovelhas deslanadas: efeito de diferentes doses de gonadotrofina coriônica eqüina sobre a taxa de ovulação. Revista Ciências Agrárias, v.41, p.215-222, 2004.

SIMPLÍCIO, A.A.; FREITAS, V.J.F.; FONSECA, J.F. Biotécnicas da reprodução como técnicas de manejo reprodutivo em ovinos. Revista Brasileira de Reprodução Animal, v.31, n.2, p.234-246, 2007.

TOSSI, B.M.; SEEKALLU, S.V.; PIERSON, R.A. et al. Evaluation of the ultrasound image attributes of developing ovarian follicles in the four follicular waves of the interovulatory interval in ewes. Theriogenology, v.72, p.902-909, 2009.

URIBE-VELÁSQUEZ, L.F.; OBA, E.; LARA-HERRERA, L.C. et al. Respostas endócrinas e ovarianas associadas com o folículo dominante da primeira onda folicular em ovelhas sincronizadas com CIDR ou PGF2 $\alpha$. Revista Brasileira Zootecnia, v.31, n.2, p.944-953, 2002.

VILARIÑO, M.; MENCHACA, A.; RUBIANES, E. Reutilização de CIDR-G usando o protocolo curta-duração em ovelhas: concentrações de progesterona sérica e dinâmica folicular. Acta Scientiae Veterinariae, v.36, Supl.2, p.487, 2008.

VIÑOLES, C.; FORSBERG, M.; BANCHERO, G. et al. Effect of long-term and short-term progestagen treatment on follicular development and pregnancy rate in cyclic ewes. Theriogenology, v.55, p.993-1004, 2001. 